Agrisaintifika

Jurnal Ilmu-Ilmu Pertanian

Vol. 2, No. 1, 2018

\title{
Peran Kelompok Tani Terhadap Tingkat Pengetahuan Petani Jambu Biji Getas Merah di Kelompok Tani Makmur Kecamatan Pagerruyung Kabupaten Kendal
}

\author{
Wahyu Puji Lestari ${ }^{1 *}$ Diah Mardiningsih ${ }^{2}$, dan Siwi Gayatri ${ }^{3}$ \\ Program Studi Agribisnis, Fakultas Peternakan dan Pertanian, \\ Universitas Diponegoro, Tembalang, Semarang 50275 - Indonesia \\ Email: wplestari10@gmail.com
}

\begin{abstract}
ABSTRAK
Tujuan penelitian ini yaitu menganalisis peran kelompok tani terhadap tingkat pengetahuan petani dalam bertani jambu biji getas merah. Penelitian telah dilaksanakan pada bulan Desember 2017 di Kelompok Tani Makmur Kecamatan Pagerruyung, Kabupaten Kendal. Metode yang digunakan dalam penelitian adalah metode survai. Pengambilan data menggunakan metode sensus kepada 32 anggota kelompok tani Makmur. Analisis data menggunakan analisis regresi linier berganda. Hasil analisis menunjukkan bahwa peran kelompok sebagai media belajar, media kerjasama, unit produksi, dan unit usaha berpengaruh secara serempak terhadap tingkat pengetahuan petani dengan angka signifikasi sebesar 0,045. Unit usaha mendapatkan angka signifikasi sebesar 0,002 , hal ini berpengaruh secara parsial terhadap tingkat pengetahuan petani. Peran kelompok sebagai media belajar sebesar 0,611, media kerjasama sebesar 0,225 , dan unit produksi sebesar 0,395 , secara parsial tidak berpengaruh signifikan terhadap pengetahuan petani.
\end{abstract}

Kata kunci : peran kelompok, pengetahuan, kelompok tani, jambu getas merah

The Role of Farmer Groups in Order to Improve Knowledge of Guava Farmers in Makmur Farmer Group Pagerguyung District Kendal Region

\begin{abstract}
The aim of study was to analyze the role of the farmer group in the knowledge level of the farmers of planting guava. The study was conducted in December 2017 at Makmur Farmer Group in Pagerruyung, Kendal Region. The method used in the study was survey. 32 respondents were selected and they were member of Makmur Group. Data were analyzed by multiple linear regression. The result of this analysis implied that the roles of farmer group as a learning activities, production unit, and business unit had simultaneously influence to the knowledge level of the farmers with signification number is 0,045. The business unit have signification number is 0,002, had significantly influences to the knowledge level of the farmers. The roles of the farmer group as a learning media is 0,611, cooperative action is 0,225 , and production unit is 0,395 , partially were not significant to the knowledge of the farmers.
\end{abstract}

Keywords : role of group, knowledge, farmer group, red brittle guava

\section{PENDAHULUAN}

Sektor pertanian di Indonesia merupakan salah satu sektor yang mendapatkan perhatian cukup besar dari pemerintah karena berperan penting dalam pembangunan ekonomi jangka panjang dan berperan dalam pemulihan ekonomi bangsa. Peranan sektor pertanian yaitu sebagai sumber penghasil bahan kebutuhan pokok, pangan, sandang dan papan, menyediakan lapangan kerja bagi sebagian besar penduduk, memberikan sumbangan terhadap pendapatan nasional yang tinggi, memberikan devisa negara, dan mengurangi ketergantungan impor (multiplier effect). Sektor pertanian dapat menjadi basis dalam mengembangkan kegiatan ekonomi melalui pengembangan usaha berbasis pertanian yaitu agribisnis dan agroindustri. Pertanian dalam arti luas yakni peternakan, perikanan, perkebunan dan pertanian yang perlu dikembangkan (Antara, 2009). Pembangunan di sektor pertanian tidak lepas dari peranan petani. Petanilah yang memelihara tanaman 
Agrisaintifika

Jurnal Ilmu-Ilmu Pertanian

Vol. 2, No. 1, 2018

Lestari, et al. 2018

dan menentukan bagaimana usahataninya harus dimanfaatkan. Petani tidak dapat memenuhi kebutuhan dan harapan seorang diri maka terbentuklah suatu kelompok.

Kelompok tani Makmur merupakan salah satu kelompok tani yang berada di Kabupaten Kendal dengan hasil produksi jambu biji getas merah yang tinggi. Kabupaten Kendal terkenal dengan sentra pertanian, salah satunya adalah budidaya jambu biji. Jambu biji getas merah (Psidium guajava L.) merupakan jenis jambu biji yang banyak dibudidayakan oleh warga Kendal. Dibentuknya kelompok tani Makmur diharapkan dapat menjalankan peran kelompok dengan baik sehingga mampu meningkatkan perilaku petani, salah satunya pengetahuan petani. Pengetahuan petani menjadi sangat penting karena diharapkan mampu membantu petani dalam meningkatkan produktivitas jambu. Adanya permasalahan tersebut, maka perlu dilakukan penelitian tentang pengaruh peran kelompok tani terhadap tingkat pengetahuan petani jambu biji getas merah. Tujuan dari penelitian ini antara lain:

1. Mendiskripsikan peran kelompok tani dalam bertani jambu biji getas merah.

2. Mendiskripsikan tingkat pengetahuan petani dalam bertani jambu biji getas merah.

3. Menganalisis peran kelompok tani terhadap tingkat pengetahuan petani dalam bertani jambu biji getas merah di kelompok tani Makmur, Kecamatan Pagerruyung, Kabupaten Kendal.

\section{METODE PENELITIAN}

\section{Metode Penentuan Lokasi}

Penentuan atau penetapan lokasi pada penelitian peran kelompok tani terhadap pengetahuan petani dilakukan dengan pertimbangan bahwa kelompok tani Makmur memiliki jumlah petani jambu biji getas merah dan jumlah produksi jambu biji getas merah terbanyak di Kecamatan Pagerruyung.

\section{Metode Penelitian dan Pengambilan Sampel}

Metode yang digunakan dalam penelitian ini adalah survey. Survey adalah penyelidikan yang diadakan untuk memperoleh fakta-fakta dari gejala yang ada dan mencari keterangan secara faktual yang dikumpulkan dari seluruh populasi atau sebagian populasi. Survey dapat dikelompokkan menjadi dua macam yaitu sensus dan survey sampel (Riyanto, 2001). Instrumen penelitian berupa kuesioner. Metode wawancara dilakukan secara langsung kepada pengurus dan anggota kelompok tani.

Metode penentuan sampel dalam penelitian ini yaitu dengan memilih seluruh anggota Kelompok Tani Makmur, yaitu sebanyak 32 anggota. Hal ini dilakukan bila jumlah populasi relatif kecil antara 30 orang, atau penelitian yang ingin membuat generalisasi dengan kesalahan yang sangat kecil. Tekhnik ini mempunyai kelebihan yaitu dapat diketahui gambaran yang sebenarnya dari suatu populasi serta tidak mempunyai sampling error (Sugiyono, 2016).

\section{Metode Pengumpulan Data}

Data yang dikumpulkan yaitu berupa data primer dan data sekunder. Data primer diperoleh dari hasil wawancara kepada responden menggunakan kuesioner yang sudah dipersiapkan. Kuesioner adalah alat pengumpulan data melalui formulir-formulir yang berisi pertanyaan yang diajukan secara tertulis pada seseorang atau sekumpulan orang untuk mendapatkan jawaban atau tanggapan dan informasi yang diperlukan oleh peneliti (Mardalis, 2008). Kuesioner dalam penelitian ini berupa pertanyaan tertutup, yaitu pertanyaan-pertanyaan yang dituliskan telah disediakan jawaban pilihan, sehingga responden tinggal memilih salah satu jawaban yang disediakan. Data sekunder yaitu data yang mendukung penelitian yang diperoleh dari literatur dan instansi terkait. 


\section{Metode Analisis Data}

Data yang terkumpul diolah terlebih dahulu kemudian dilakukan analisis secara deskriptif dan kuantitatif lalu dilakukan analisis sesuai dengan tujuan penelitian. Analisis deskriptif yaitu dilakukan agar dapat menggambarkan bagaimana hasil wawancara dengan informan yaitu anggota kelompok tani mengenai seberapa jauh peranan kelompok tani dalam menjalankan fungsinya sebagai kelas belajar, wahana kerja sama, unit produksi, dan unit bisnis. Data yang diperoleh dari kuesioner akan diolah dengan skala likert untuk kemudian digolongkan pada kriteria penilaian responden. Tiap pertanyaan dari variabel menggambarkan masing-masing variabel diberi nilai skor yang berkisar 1 (rendah), 3 (sedang) dan5 (tinggi).

Penentuan posisi tanggapan sampel dapat ditentukan dengan menggunakan rentang skala penilaian. Rentang skala dihitung dengan menggunakan rumus sebagai berikut:

$$
\mathrm{Rs}_{\mathrm{s}}=\frac{\text { bobot terbesar-bobot terkecil }}{\mathrm{n}}
$$

Keterangan:

Rs = rentang skala

$\mathrm{n}$ = banyaknya kategori bobot

Analisis kuantitatif dilakukan untuk mengetahui tingkat pengaruh variabel dalam faktor yang berpengaruh terhadap kinerja petani yaitu dengan menggunakan analisis regresi linier berganda. Perhitungan rumus regresi linier berganda yaitu :

$$
Y=a+b 1 X 1+b 2 X 2+b 3 X 3+b 4 X 4+e
$$

Keterangan :

$$
\text { Y : Tingkat pengetahuan petani }
$$

(skor)

$\begin{array}{ll}\text { a } & \text { : Nilai konstanta } \\ \mathrm{b}(1,2,3, . .) & \text { : Nilai koefisien regresi } \\ \mathrm{e} & \text { : Error } \\ \mathrm{X} 1 & \text { : Media belajar (skor) } \\ \mathrm{X} 2 & \text { : Kerjasama (skor) } \\ \mathrm{X} 3 & \text { : Unit Produksi (skor) } \\ \mathrm{X} 4 & \text { : Unit usaha (skor) }\end{array}$

Data yang diperoleh kemudian diuji kenormalannya menggunakan uji Kolmogorov-smirnov kemudian diuji dengan asumsi klasik multikolinearitas, heteroskedastisitas dan autokorelasi. Jika data normal terpenuhi maka analisis data mengunakan regresi linier berganda, jika data tidak normal maka menggunakan analisis korelasi spearman (Ghozali, 2005).

Uji $F$ digunakan untuk mengetahui pengaruh variabel independen dengan dependen secara serempak. Hipotesis statistik yang diambil sebagai berikut:

$$
\begin{aligned}
& \mathrm{H}_{0}: b_{1}=b_{2}=b_{3}=b_{4}=0 \\
& \mathrm{H}_{1}: b_{1} \neq b_{2} \neq b_{3} \neq b_{4} \neq 0 \\
& \mathrm{H}_{0}=\text { Tidak ada pengaruh dari variabel }
\end{aligned}
$$
independen terhadap variabel dependen.

$\mathrm{H}_{1}=$ Ada pengaruh dari variabel independen terhadap variabel dependen untuk minimal satu variabel independen.

Kriteria pengambilan keputusan yaitu:

$\mathrm{H}_{0}$ ditolak dan $\mathrm{H}_{1}$ diterima jika sig $\mathrm{git}_{\mathrm{b}} \leq$ 0,05 .

$\mathrm{H}_{1}$ ditolak dan $\mathrm{H}_{0}$ diterima jika sig ${ }_{\mathrm{bit}}>$ 0,05 .

Uji $\mathrm{T}$ digunakan untuk mengetahui besarnya pengaruh variabel independen dan dependen secara parsial. Hipotesis statistik yang diambil adalah sebagai berikut

$$
\begin{aligned}
& \mathrm{H}_{0}: b_{1}=0 ; b_{2}=0 ; b_{3}=0 ; b_{4}=0 \\
& H_{1}: b_{1} \neq 0 ; b_{2} \neq 0 ; b_{3} \neq 0 ; b_{4} \neq 0 \\
& H_{0}=\text { Tidak ada pengaruh dari variabel } \\
& \text { independen ke } n \text { terhadap variabel } \\
& \text { dependen. }
\end{aligned}
$$

$\mathrm{H}_{1}=$ Ada pengaruh dari variabel independen ke $\mathrm{n}$ terhadap variabel dependen.

Kriteria pengambilan keputusan yaitu:

$\mathrm{H}_{0}$ ditolak dan $\mathrm{H}_{1}$ diterima jika sig ${ }_{\text {bit }} \leq$ 0,05 .

$\mathrm{H}_{1}$ ditolak dan $\mathrm{H}_{0}$ diterima jika sig bit $>$ 0,05 .

Apakah model regresi yang dihasilkan ditentukan adanya korelasi antar variabel bebas dapat diuji dengan uji multikolinearitas. Multikolinearitas dapat dilihat dari tolerance dan Variance Inflation Factor (VIF) dengan ketentuan: Dikatakan multi apabila nilai VIF < 10. Mempunyai angka tolerance $>0,10$

Apakah dalam model regresi terjadi ketidaksamaan varians dari residual satu 
Agrisaintifika

pengamatan ke pengamatan yang lain perlu diuji dengan uji heteroskedastisitas dengan melihat Grafik Scatterplot.

Dasar pengambilan keputusan:

1. Jika terdapat pola tertentu pada Grafik Scatterplot, titik-titik yang membentuk pola teratur (bergelombang, menyebar kemudian menyempit) maka disimpulkan terjadi heteroskedatisitas.

2. Jika tidak ada pola yang jelas, serta titik-titik menyebar, maka indikasinya tidak terjadi heteroskedatisitas.

Apakah asumsi variabel dependen tidak berkorelasi dengan dirinya sendiri, atau dengan kata lain nilai dari variabel dependen tidak berhubungan dengan nilai variabel itu sendiri, baik nilai periode sebelumnya atau nilai periode sesudahnya dapat diuji dengan uji autokorelasi dengan Durbin-Watson.

$\mathrm{Ho}=$ tidak terdapat autokorelasi

$\mathrm{Hi}=$ terdapat autokorelasi

Dasar pengambilan keputusan:

1. Jika $\mathrm{d}<\mathrm{dL}$ atau $>(4-\mathrm{dL})$ maka Ho ditolak sehingga terdapat autokorelasi.

2. Jika d terletak antara dU dan (4-dU), maka Ho diterima sehingga tidak terdapat autokorelasi.

3. Jika d terletak antara dL dan dU atau diantara (4-dU) dan (4-dL), maka tidak menghasilkan kesimpulan yang pasti.

\section{HASIL DAN PEMBAHASAN}

\section{Deskripsi Variabel Penelitian Pengetahuan Petani}

Pengetahuan petani di kelompok tani Makmur sebagian besar (94\%) pada kategori baik. Hasil deskriptif menunjukkan skor terendah (minimum) sebesar 132, skor tertinggi (maksimum) sebesar 180 dengan range 48. Rata-rata skor jawaban dari variabel tersebut adalah 168,69 dan nilai standar deviasi sebesar 14,52. Penilaian pengetahuan petani dilihat dari kemandirian petani dalam melaksanakan usahatani jambu biji getas merah, keinginan petani dalam kegiatan rutin kelompok, bahkan turut mengambil bagian dari kelompok tani (menjadi pengurus kelompok). Seluruh anggota kelompok tani Makmur memiliki tingkat pengetahuan bertani jambu biji getas merah yang baik. Petani di kelompok tani Makmur mendapatkan pengetahuan bertani yaitu dengan turut dalam kegiatan kelompok tani, pengalaman dalam berusahatani, cakrawala, serta pengetahuan yang diperoleh dari pendidikan formal maupun non formal. Hal ini sesuai pendapat Ardi (2015) bahwa dengan tingkat pengetahuan yang baik mampu memunculkan sikap seseorang terhadap suatu objek tertentu yang dipengaruhi faktor pengalaman, proses belajar, dan kegiatan organisasinya.

\section{Peran Kelompok Tani sebagai Media Belajar}

Peran kelompok tani sebagai media belajar di kelompok tani Makmur sebagian besar $(84 \%)$ pada kategori baik. Hasil deskriptif menunjukkan bahwa skor terendah (minimum) sebesar 24 dan skor jawaban tertinggi (maksimum) sebesar 50 dengan range 26. Rata-rata skor jawaban dari variabel tersebut adalah 44,75 dam standar deviasi 5,69. Hasil tersebut dikatakan baik karena kelompok tani Makmur mampu mengajak anggota kelompok untuk terlibat dan berpartisipasi dalam kegiatan kelompok. Beberapa aktivitas yang dilakukan kelompok untuk meningkatkan pengetahuan petani adalah pertemuan kelompok secara rutin dan aktivitas pembinaan serta pelatihan dalam kelompok. Aktivitas pembinaan dan pelatihan dalam kelompok diwujudkan dengan praktek pembuatan olahan jambu biji getas merah.

Pelatihan pembuatan olahan tersebut belum sepenuhnya diterapkan oleh seluruh anggota kelompok tani. Kelompok aktif dalam penyebaran ilmu pengetahuan, dengan menyebarkan informasi dari pemerintah untuk meningkatkan produksi. Kelompok mampu mengembangkan dan menumbuhkan motivasi kepada anggotanya dengan cara menyebarkan informasi antar anggota kelompok tani. Berdasarkan wawancara 
dengan salah satu petani fungsi kelompok sebagai tempat kegiatan belajar mampu menghasilkan produk sesuai yang diharapkan, serta mampu meningkatkan pendapatan keluarga dan kelompok mampu memecahkan masalah yang dihadapi oleh petani secara bersama-sama. Hal ini sesuai pendapat Yenni et al., (2014), bahwa kelompok mampu menjadi wadah kegiatan belajar bagi anggotanya guna meningkatkan pengetahuan, ketrampilan, dan sikap serta kemandirian dalam berusahatani sehingga mampu meningkatkan produktivitas.

\section{Peran Kelompok Tani sebagai Media Kerjasama}

Peran kelompok tani sebagai media kerjasama di kelompok tani Makmur sebagian besar $(78 \%)$ pada kategori baik. Hasil deskriptif menunjukkan bahwa skor terendah sebesar 34 dan skor jawaban tertinggi sebesar 46 dengan range 12 . Ratarata skor jawaban dari variabel tersebut adalah 40,06 dan standar deviasi 2,89. Peran kelompok sebagai media kerjasama dikatakan baik karena pembagian tugas dan wewenang dalam struktur organisasi jelas, yaitu ada ketua, wakil ketua, bendahara, dan sekertaris. Kelompok tani Makmur memiliki rasa kebersamaan, solidaritas, dan kekompakan yang tinggi dalam upaya meningkatkan produktivitas produk untuk menunjang kesejahteraan anggota kelompok tani. Kebersamaan dan kekompakan dalam kelompok diwujudkan dalam kegiatan bersama, seperti pembuatan sarana produksi. Anggota kelompok tani Makmur telah terbiasa memecahkan masalah secara bersama dan dibahas ketika ada pertemuan kelompok.

Salah satu wujud kerjasama dalam menyelesaikan masalah yaitu ketika terjadi kemarau panjang, dan terjadi kekeringan yang akhirnya terjadi penurunan produksi. Kelompok tani Makmur memiliki perwujudan kerjasama atau semangat saling membantu dalam kelompok salah satunya dengan pembuatan sistem irigasi yaitu dengan bersama-sama membuat saluran air yang digunakan secara bergilir. Peran kelompok tani sebagai wadah kerjasama dapat berjalan dengan baik dikarenakan prinsip kekeluargaan dan gotong royong dalam masyarakat yang sudah berjalan lama dan antar petani telah mengenal satu sama lain dengan baik. Hal ini sesuai pendapat Wiranti (2012) menyatakan bahwa kerjasama bermacam-macam bentuknya. Salah satunya dapat diwujudkan dengan semangat gotong royong yaitu dengan bekerja bersama-sama untuk mencapai tujuan bersama dan merupakan suatu proses yang paling dasar. Kelompok tani Makmur mengadakan kerjasama dalam membantu permodalan anggota. Kelompok tani Makmur menjalin kerjasama dengan LKM (Lembaga Keuangan Mikro) dan BUMDES (Badan Usaha Milik Desa) yang terkait dengan administrasi, seperti simpan pinjam maupun permodalan usahatani. Kelompok tani Makmur telah menjalin kerjasama dengan Universitas Diponegoro dalam hal pengetahuan produk dan pembuatan pupuk kompos. Kelompok tani bekerjasama dengan pemerintah Kabupaten Kendal berupa bantuan peralatan pengolahan hasil pertanian dan pembuatan desa wisata. Hal ini sesuai pendapat Yenni et al., (2014) bahwa kelompok tani merupakan tempat untuk memperkuat kerjasama baik di antara sesama petani dalam kelompok tani dan antar kelompok tani maupun dengan pihak lain seperti pemerintah atau instansi terkait. Kekurangan dari peran kelompok sebagai media kerjasama yaitu belum adanya wujud kerjasama dalam proses perawatan, panen, dan pasca panen, sehingga diharapkan kedepannya kelompok mampu melaksanakan sehingga akan diperoleh produktivitas yang baik.

\section{Peran Kelompok Tani sebagai Unit Produksi}

Peran kelompok sebagai unit produksi di kelompok tani Makmur sebagian besar (63\%) pada kategori sedang. Hasil analisis deskriptif menunjukkan skor terendah (minimum) sebesar 26 dan skor jawaban tertinggi (maksimum) sebesar 46 dengan range 20. Rata-rata skor jawaban dari variabel tersebut adalah 36,5 dan standar 
Agrisaintifika

deviasi 3,4. Peran kelompok sebagai unit produksi terbilang cukup baik karena kelompok mampu mengambil keputusan dalam pengembangan produksi yang menguntungkan seperti penyedian fasilitas dan sarana produksi. Adanya fasilitas dan sarana produksi yang disediakan kelompok sangat bermanfaat untuk meningkatkan produksi. Kelompok mampu menyediakan peralatan seperti traktor dan peralatan pengolahan pasca panen dalam memfasilitasi kebutuhan anggotanya. Kelompok tani Makmur mampu menyediakan sarana irigasi, sehingga petani akan lebih mudah mendapatkan sumber air untuk pengairan lahannya. Hal ini sesuai dengan pendapat Yenni et al., (2014) bahwa kelompok tani sebagai unit produksi harus dapat mengambil keputusan dalam menyediakan pengembangan produksi yang menguntungkan berdasarkan informasi yang tersedia dalam bidang teknologi, sosial, permodalan, sarana produksi, dan sumberdaya lainnya. Peran kelompok tani sebagai unit produksi memang belum terwujud dengan baik, dilihat belum sepenuhnya mampu memenuhi kebutuhan produksi anggota kelompok. Saat ini kelompok tani Makmur belum mampu memfasilitasi anggotanya seperti penyediaan pupuk, pestisida, maupun menyediakan sarana dalam proses pemanenan. Kelompok belum sepenuhnya mampu menyediakan tempat pengepulan untuk menampung hasil pasca panen. Menurut pendapat Effendi (2012) bahwa sebagai unit produksi yang dinamis dan berperan secara baik harus memenuhi beberapa indikator, yaitu pengelolaan pasca panen yang baik, penanganan terhadap penyimpanan hasil panen, pengelolaan hasil panen, serta usaha dalam peningkatan produksi.

\section{Peran Kelompok Tani sebagai Unit Usaha}

Peran kelompok sebagai unit usaha di kelompok tani Makmur sebagian besar (94\%) pada kategori baik. Hasil analisis statistik menunjukkan nilai skor terendah (minimum) sebesar 34 dan skor jawaban tertinggi (maksimum) sebesar 50 dengan range 16 . Rata-rata skor jawaban dari variabel tersebut adalah 46,25 dan standar deviasi 3,5. Kelompok tani Makmur dapat menjalankan perannya sebagai unit usaha dan mampu meningkatkan pendapatan anggotanya berupa pemberian fasilitas permodalan. Fasilitas permodalan tersebut berupa bantuan dana dari pemerintah yang dikelola bersama LKM (Lembaga Keuangan Mikro) sebesar Rp 100.000.000,- dan dimanfaatkan kelompok untuk dana simpan pinjam anggota. Kelompok mampu membantu kelancaran dalam pemasaran jambu biji getas merah dan mampu memberikan informasi dalam memanfaatkan peluang dan kesempatan berusaha. Kelompok dapat menghubungkan anggotanya untuk memasarkan hasil panennya di pameran pertanian yang diadakan oleh pemerintah, sehingga didapatkan harga yang lebih tinggi. Hal ini akan berpengaruh dengan peningkatan kemandirian dan keswadayaan anggota. Hal ini sesuai dengan pendapat Asfiansyah (2014) bahwa peran kelompok sebagai unit usaha berkaitan dengan kegiatan bisnis yang berorientasi pada profit, sehingga kelompok tani mampu menjadi agen bisnis yang bisa menggerakkan sumberdaya kolektif (tenaga, pikiran, dan dana) bagi kepentingan kelompok. Kelompok mampu memberi pengarahan untuk pengolahan pasca panen, namun baru beberapa anggota yang menjalankan usaha pengolahan pasca panen jambu biji getas merah. Menurut pendapat Effendi (2012) bahwa peran kelompok tani sebagai unit usaha harus mampu menumbuhkan kreativitas dan prakarsa anggota kelompok tani untuk memanfaatkan setiap peluang usaha, informasi, dan akses permodalan yang ada.

\section{Analisis Regresi Linier Berganda Uji Parsial (Uji T)}

Uji $t$ bertujuan untuk mengetahui pengaruh peran kelompok tani terhadap 
Tabel 1. Hasil Uji Parsial

\begin{tabular}{lc}
\hline \hline \multicolumn{1}{c}{ Variabel } & Uji Parsial \\
\hline Media belajar & 0,611 \\
Media kerjasama & 0,225 \\
Unit produksi & 0,395 \\
Unit usaha & 0,002 \\
\hline
\end{tabular}

Berdasarkan tabel hasil uji parsial variabel media belajar memiliki angka signifikansi sebesar 0,611 dengan tingkat signifikansi $95 \%(\alpha=0,05)$. Angka signifikansi (P Value) pada variabel media belajar lebih besar dari 0,05 . Atas dasar perbandingan tersebut maka variabel media belajar secara parsial tidak berpengaruh dengan pengetahuan petani $\left(\mathrm{H}_{0}\right.$ diterima, $\mathrm{H}_{1}$ ditolak). Bentuk media belajar yang diterapkan kelompok yaitu dengan pertemuan rutin kelompok yang nantinya akan diisi dengan kegiatan atau aktivitas pelatihan dan pembinaan. Pelatihan dan pembinaan yang telah dilaksanakan di Kelompok tani Makmur yaitu pembuatan olahan jambu, dan pembuatan pupuk kompos (salah satunya bersama tim peneliti Universitas Diponegoro). Kegiatan pelatihan dan pembinaan tersebut diharapkan mampu menghasilkan produk yang lebih baik. Kelompok diharapkan mampu membantu memecahkan masalah yang dihadapi oleh anggotanya, seperti masalah yang terjadi ketika musim kemarau dimana produktivitas akan mengalami penurunan. Peran kelompok tani Makmur sebagai media belajar belum sepenuhnya mampu meningkatkan pengetahuan petani, dan belum terlaksana dengan baik. Kelompok tani Makmur masih jarang mengadakan kunjungan belajar untuk meningkatkan pengetahuan petani. Selain diadakan kunjungan, perlu adanya sistem pelajaran dengan memanfaatkan media deseminasi. Media deseminasi dapat berupa dari media cetak (folder, booklet dan poster), media audio (radio), dan media audio-visual (CD interaktif). Hal ini sesuai pendapat Kartono (2014) menyatakan bahwa perlu penggunaan media dalam menerapkan proses belajar dalam kelompok melalui pancaindera yang hasilnya akan berupa nilai pengetahuan petani.

Variabel media kerjasama memiliki angka signifikansi sebesar 0,225 lebih besar dari 0,05 . Derajat yang digunakan yaitu $95 \%$ ( $\alpha=$ $0,05)$. Atas dasar perbandingan tersebut maka variabel media kerjasama secara parsial tidak berpengaruh terhadap pengetahuan petani $\left(\mathrm{H}_{0}\right.$ diterima, $\mathrm{H}_{1}$ ditolak). Bentuk kerjasama yang diterapkan oleh kelompok tani Makmur yaitu dengan memberikan pembagian tugas dan memiliki struktur organisasi yang jelas. Dengan pembagian tugas yang jelas, akan lebih mudah mewujudkan kekompakan kelompok dalam mencapai tujuan. Sesama anggota kelompok tani memiliki rasa kepedulian yang tinggi, diwujudkan dengan kekompakan anggota kelompok dalam membuat saluran air untuk mengairi lahan pertanian. Kerjasama yang dilakukan oleh kelompok tani tidak hanya dari dalam, namun kelompok tani Makmur mampu bekerjasama dengan instansi lain yang terkait. Ada bentuk kerjasama kelompok tani Makmur dengan Gapoktan di kecamatan Pagerruyung yaitu dengan adanya kegiatan bersama seperti pembinaan maupun urusan penjualan hasil produk, sehingga kegiatan tersembut mampu meningkatkan pengetahuan dan kerampilan petani. Kelompok tani Makmur bekerjasama dengan pemerintah seperti LKM (Lembaga Keuangan Mikro) dan BUMDES (Badan Usaha Milik Desa) dalam membantu permodalan anggota kelompok berupa dana arisan maupun simpan pinjam. Hal ini sesuai dengan pendapat Yenni et al., (2014) yang mengatakan bahwa melalui kelompok tani petani dapat meningkatkan kerjasama dan mudah memperoleh modal dan saprodi dan dapat meningkatkan perilaku petani dalam 
Agrisaintifika

bertani. Hasil penelitian menjelaskan media kerjasama tidak berpengaruh positif dengan pengetahuan petani. Hal ini dapat dilihat bahwa kelompok tani Makmur belum sepenuhnya menjalankan perannya. Belum ada perwujudan kerjasama antar anggota dalam proses perawatan, seperti pemupukan, menyiangi, atau memberi pelindung buah. Kegiatan pembinaan dalam pengolahan produk jambu biji getas merah sering dilakukan namun belum ada perwujudan kerjasama dalam pengolahan pasca panen. Peran kelompok sebagai media kerjasama di kelompok tani Makmur masih perlu digiatkan. Menurut Asfiansyah (2014), dalam melakukan usahatani, tidak semua kegiatan dapat dilakukan secara individual sehingga diperlukan kerjasama antar anggota kelompok tani, misalnya dalam pemasaran, pengendalian hama dan penyakit, pemupukan, atau pengairan.

Variabel unit produksi dengan tingkat signifikansi 95\% $(\alpha=0,05)$ diperoleh hasil sebesar 0,395. Angka signifikansi ( $P$ Value) pada variabel unit produksi lebih besar dari 0,05 . Atas dasar perbandingan tersebut maka variabel unit produksi secara parsial tidak berpengaruh terhadap pengetahuan petani $\left(\mathrm{H}_{0}\right.$ diterima, $\mathrm{H}_{1}$ ditolak). Kelompok tani Makmur dapat menjalankan perannya sebagai unit produksi namun bentuk kegiatannya belum berpengaruh positif dengan pengetahuan petani. Dari hasil penelitian menunjukkan jika kelompok belum mampu menyediakan sarana produksi seperti penyediaan pupuk, pestisida, atau sarana pemanenan yang mencukupi. Menurut Asfiansyah (2014), kelompok tani harus bisa mengfasilitasi kegiatan produksi bagi anggota-anggotanya, mulai dari penyediaan input, proses produksi, pasca panen, sampai dengan pemasaran hasilnya. Kelompok tani Makmur belum sepenuhnya mampu menyediakan tempat pengepulan untuk menampung hasil panen. Bentuk peran kelompok sebagai unit produksi yang telah diterapkan dikelompok tani Makmur yaitu mampu mengfasilitasi anggota kelompok dalam sarana irigasi. Kelompok tani Makmur memiliki sarana produksi untuk pengolahan lahan berupa traktor dan bisa dipakai oleh anggotanya. Kelompok tani Makmur dapat memenuhi peran sebagai unit produksi dengan adanya bantuan dari pemerintah berupa alat pengolahan pasca panen. Sarana dan prasarana tersebut mampu membantu anggotanya untuk mengembangkan usahataninya. Kelompok mampu mengambil keputusan dalam menentukan pengembangan produksi yang menguntungkan berdasarkan informasi di bidang teknologi, salah satunya dengan pemanfaatan alat pengolahan pasca panen. Kelompok mampu meningkatkan kesinambungan produksi dan kelestarian SDA (Sumber Daya Alam) yaitu dengan tidak mencemari lingungan dengan bahan kimia yang berlebih. Menurut Putra et al., (2016), peran kelompok tani dalam melakukan kegiatan pelestarian lingkungan harus diterapkan.

Variabel unit usaha dengan tingkat signifikansi 95\% $(\alpha=0,05)$ diperoleh hasil sebesar 0,002 . Angka signifikansi ( $P$ Value) pada variabel unit usaha lebih kecil dari 0,05. Atas dasar perbandingan tersebut maka variabel unit usaha secara parsial berpengaruh terhadap pengetahuan petani $\left(\mathrm{H}_{0}\right.$ ditolak, $\mathrm{H}_{1}$ diterima). Peran kelompok sebagai unit usaha di kelompok tani Makmur sudah berjalan dengan baik. Dari hasil penelitian dengan adanya kelompok tani Makmur sebagai unit usaha, petani memiliki pengaruh langsung dengan pengetahuan mereka. Kelompok tani Makmur mampu memberikan peluang dan kesempatan meningkatkan usahatani anggotanya. Kelompok tani dapat berperan dalam kegiatan bisnis anggotanya yaitu memasarkan hasil produksi. Hal ini sesuai pendapat Asfiansyah (2014) yang menyatakan bahwa usahatani pada umumnya adalah kegiatan bisnis yang berorientasi pada profit. Kelompok tani Makmur memiliki fasilitas permodalan untuk anggotanya dalam meningkatkan usahanya 
dan didukung dengan kondisi di kelompok tani Makmur dimana administrasi keuangan sudah berjalan dengan baik. Ada fasilitas kelompok untuk menjual hasil produksi anggotanya ke koperasi desa, maupun ke instansi seperti ke pameran yang biasa diadakan oleh pemerintah.

\section{Uji Simultan (Uji F)}

Berdasarkan hasil uji $f$ pada penelitian ini didapatkan nilai $f$ hitung sebesar 0,630 dengan angka signifikansi ( $P$ value) sebesar 0,045 . Tingkat signifikansi yang dipakai yaitu $95 \%(\alpha=0,05)$. Angka signifikansi ( $P$ value) sebesar $0,045<0,05$. Atas dasar perbandingan tersebut, maka $\mathrm{HO}$ ditolak, $\mathrm{H}_{1}$ diterima atau variabel media belajar, media kerjasama, unit produksi, dan unit usaha mempunyai pengaruh yang signifikan secara bersama-sama terhadap variabel pengetahuan petani. Peran kelompok tani dapat dimaksimalkan, karena adanya kepentingan yang sama diantara anggotanya. Hal ini sesuai dengan pendapat Mayasari (2013) yang menyatakan bahwa kelompok tani mampu menjalankan perannya didukung dengan adanya kepentingan yang sama, tanggung jawab bersama diantara anggotanya, adanya kader tani yang berdedikasi untuk menggerakkan para petani dan kepemimpinannya diterima oleh sesama petani lainnya, adanya kegiatan yang dapat dirasakan manfaatnya oleh sebagian besar anggotanya, serta adanya dorongan atau motivasi dari tokoh masyarakat setempat untuk menunjang program yang telah ditentukan.

\section{Persamaan Regresi Linier Berganda}

Berdasarkan tabel hasil uji didapatkan persamaan regresi linier berganda sebagai berikut:

$Y=225,7+0,245 X_{1}-0,753 X_{2}-0,693 X_{3}+$ $0,076 X_{4}$

Dari hasil persamaan diatas dapat dijelaskan sebagai berikut: Nilai 0,245 pada variabel media belajar (X1) bernilai positif, dapat dikatakan bahwa setiap perubahan satu unit nilai variabel $X_{1}$ akan meningkatkan nilai $Y$ sebesar 0,245. Hal ini menunjukkan peran kelompok tani Makmur sebagai media belajar berpengaruh positif terhadap pengetahuan petani. Nilai - 0,753 pada variabel media kerjasama (X2) bernilai negatif, maka setiap perubahan satu unit nilai variabel $X 2$ akan menurunkan nilai $Y$ sebesar $-0,753$. Hal ini menunjukkan bahwa peran kelompok tani Makmur sebagai media kerjasama tidak berpengaruh positif terhadap pengetahuan petani. Nilai - 0,693 pada variabel unit produksi (X3) bernilai negatif, dapat dikatakan bahwa setiap perubahan satu unit nilai variabel $X_{3}$ akan menurunkan nilai $Y$ sebesar - 0,693. Hal ini menunjukkan bahwa peran kelompok tani Makmur sebagai unit produksi tidak berpengaruh positif terhadap pengetahuan petani jambu biji getas merah. Nilai 0,076 pada variabel unit usaha $(X 4)$ bernilai positif, dijelaskan bahwa setiap perubahan satu unit nilai variabel $X_{4}$ akan meningkatkan nilai $Y$ sebesar 0,076 . Hal ini menunjukkan bahwa peran kelompok tani sebagai unit usaha berpengaruh signifikan terhadap pengetahuan petani jambu biji getas merah. Peran kelompok tani sebagai media belajar $\left(X_{1}\right)$, media kerjasama $\left(X_{2}\right)$, dan unit produksi $\left(\mathrm{X}_{3}\right)$ tidak berpengaruh terhadap tingkat pengetahuan petani. Peran kelompok sebagai unit usaha berpengaruh secara signifikan dalam meningkatkan pengetahuan petani. Semakin baik kinerja kelompok sebagai unit usaha akan berdampak pada peningkatan pengetahuan petani di kelompok tani Makmur.

\section{KESIMPULAN}

1. Peran kelompok tani sebagai media belajar, media kerjasama, dan unit usaha dalam kategori baik, sedangkan peran kelompok tani sebagai unit produksi cukup baik dalam menjalankan perannya.

2. Peran kelompok tani sebagai media belajar, media kerjasama, unit produksi, dan unit usaha mempunyai pengaruh yang signifikan terhadap tingkat pengetahuan petani tentang jambu biji getas merah.

3. Secara parsial hasil uji $t$, peran kelompok tani sebagai unit usaha berpengaruh 
Lestari, et al. 2018

terhadap tingkat pengetahuan petani tentang budidaya jambu biji getas merah.

\section{DAFTAR PUSTAKA}

Antara, Made. 2009. Pertanian, Bangkit atau Bangkrut. Anti Foundation, Denpasar.

Ardi, Muhammad. 2015. Perilaku Petani Tegalan Dalam Meningkatkan Kualitas Lingkungan Di Kabupaten Soppeng. J. Scientific Pinisi. 1 (1): 14 - 15.

Asfiansyah, Azzam Hakam. 2014. Peran Kelompok Tani Terhadap Usaha Peningkatan Pendapatan Anggota Melalui Program Kemitraan Usahatani. J. IImiah. 3 (1): 23 -35.

Effendi, Muhammad. 2012. Peranan Kelompok Tani Dalam Meningkatkan Kemandirian Petani Di Kabupaten Tanah Tidung. J. Ziraa'ah. 35 (3): 204 216.

Ghozali, Imam. 2005. Aplikasi Analisis Multivariate Dengan Program SPSS. BP Universitas Diponegoro, Semarang.

Kartono. 2014. Peningkatan Pengetahuan Petani Melalui Penggunaan Media Penyuluhan Di Provinsi Banten. J. Buletin IKATAN. 4 (1): 29 - 38.

Mardalis. 2008. Metode Penelitian Suatu Pendekatan Proposal. Bumi Aksara, Jakarta.

Mayasari, Fitri. 2013. Pengaruh keberadaan kelompok tani terhadap pendapatan usaha tani tembakau. J. Artikel IImiah. 1 (3) : 28-35.

Putra, B.L., E. Sayamar. dan E. Tety. 2016. Peran kelompok tani dalam meningkatkan pendapatan petani swadaya kelapa sawit di Desa Bukit Lingkar Kecamatan Batang Cenaku Kabupaten Indragriri Hulu. J. Jom Kaperta. 3 (2) : 1-12.

Riyanto, Yatim. 2001. Metodologi Penelitian Pendidikan. SIC, Surabaya.
Sugiyono. 2016. Metode Penelitian Administrasi. CV Alfabeta, Bandung.

Wiranti, Sri Setyani. 2012. Membangun kerjasama tim. J. STIE Semarang. 4 (3) : 59-65.

Yenni, C.W., Sunarru, S.S., Subejo. 2014. Peran Kelompok Tani Dalam Penerapan SRI (System of Rice Intensification) Di Kecamatan Kalikajan Kabupaten Wonosobo. J. Agro Ekonomi. 24(1) : $84-93$. 